\title{
A SZKIZOFRÉNIA TUDATELMÉLETI KUTATÁSA
}

\author{
EGYED KATALIN-JUHÁSZ LEVENTE ZSOLT
}

ELTE Pszichológiai Intézet, Budapest

E-mail: kegyed@izabell.elte.hu; juhaszle@izabell.elte.hu

\begin{abstract}
A cikk a szkizofrénia neurokognitív elméleteinek jellegzetes képviselöjét, a mentalizációs deficit hipotézist mutatja be. C. FRITH (1992) elképzelése szerint a szkizofrénia tüneteinek és viselkedéses jellegzetességeinek nagy része egyetlen funkció, a tudatelmélet sérülésének következménye. Írásunkban a tudatelmélet fejlödéslélektani és autizmussal kapcsolatos kutatásának tapasztalataira alapozva kritikai áttekintését adjuk az elmélet indukálta empirikus vizsgálatok eredményeinek.
\end{abstract}

Kulcsszavak: $\quad$ szkizofrénia, tudatelmélet, végrehajtó funkció, autizmus

A szkizofrénia összetett, változatos tünetekkel jellemezhető pszichiátriai kórkép, amelynek etiológiája nem tekinthető tisztázottnak, noha számos elmélet és kutatás született e betegséget meghatározó tényezők felderítésére (BITTER, FÜREDI [szerk.], 2000). Ezek közül egy olyan, a kurrens neurokognitív szemléletbe (GREEN, 1998) illeszthető elméletet, illetve az ahhoz kapcsolódó kutatásokat mutatjuk be, amely a pszichológiai szintű magyarázatot kitüntetettnek - bár természetesen nem kizárólagosnak - tekinti.

Cristopher FRITH $(1992 ; 1994)$ a közismerten tünetgazdag szkizofrénia hátterében egyetlen kognitív képesség zavarát feltételezi. Számos tünetet - negatív (például alógia, érzelmi elsivárosodás, anhedónia, aszocialitás stb.) és pozitív ${ }^{1}$ (például hallucinációk, téveszmék, formális gondolkodás zavara, szétesett vagy bizarr magatartás) tüneteket egyaránt - megmagyarázni látszik, ha feltételezzük, hogy a mentalizációs képesség sérül. Vagyis az a naiv pszichológiának vagy tudatelméletnek nevezett képességünk, amelynek segítségével értelmezni, magyarázni, elővételezni, manipulálni tudjuk akár a saját, akár mások viselkedését úgy, hogy különböző

${ }^{1}$ Negatív (vagy hiány-) tünet: a normálisan meglévő mentális funkciók elégtelen működése; pozitíu tünet: a normális mentális funkciókhoz képest pluszban jelentkező, kóros mentális működés (ANDREASEN, 1982; Crow, 1980). 
mentális állapotokat - például célt, szándékot, vágyat, vélekedést - tulajdonítunk magunknak és másoknak. Ez az evolúciós szempontból is magas adaptív értékkel bíró kognitív funkció az (DENNETT, 1996), amely egységes magyarázatául szolgálhat a szkizofrénia tüneteinek FRITH (1992) által elkülönített három területén. Ezek:

1. az akarati viselkedés,

2. az énmonitorozás,

3. mások szándékainak és mások mentális állapotainak monitorozása.

\section{A SZKIZOFRÉNIA TÜNETEINEK TUDATELMÉLETI ÉRTELMEZÉSE}

\section{Az akarati viselkedés zavarának tünetei:}

- A szegényes viselkedés, amely kiterjedhet a mozgásra, a beszédre és az érzelmekre is.

- A spontán cselekvések csökkenése. Külső ingerekre adott viselkedés generálására képes a beteg, de képtelen a saját akarata szerint viselkedni.

- Ugyanakkor a beteg nem tudja elnyomni a felbukkanó nem megfelelő reakciót, vagyis a válasz perszeverálódik, és ez viselkedéses sztereotípiákhoz, a beszéd inkoherenciájához és az affektusok inkongruenciájához vezet.

- Visszahúzódó viselkedés.

Frith tudatelméleti megközelítésében: a fenti tünetek esetén a beteg nincs tudatában problémáinak, nem érti a saját céljait. Tehát önmaguk mentalizálása szenved zavart.

\section{Az énmonitorozás zavarának tünetei:}

- Idegen kontroll (befolyásoltsági) téveszme.

- Egyes hallási hallucinációk.

- Nincsen a páciens tudatában saját szándékainak.

A tünetek e csoportja a tudatelméleti megközelítésben: a fenti tünetek esetén a beteg nincs tudatában, nem érti a saját szándékait és egyéb saját mentális állapotát. Tehát szintén az egyes szám első személyű mentalizálás érintett.

\section{Mások szándékainak monitorozásában mutatkozó zavar tünetei:}

- Vonatkoztatási problémák,

- Paranoid tünetek,

- Inkoherencia,

- Harmadik személyủ hallucináció.

A tünetek e csoportja a tudatelméleti megközelítésben azt jelenti, hogy a beteg nincs tudatában, nem érti mások szándékait és egyéb mentális állapotait. Vagyis egy másik ágens mentalizálása szenved zavart.

A mentalizálás során - amikor például rosszindulatot tulajdonítunk egy megjegyzésnek (szándék tulajdonítása), kitaláljuk, hogy egy gyerek miért nézi sóvárogva barátja biciklijét (vágy tulajdonítása), rájövünk, hogy szerencsére a főnök is tévedhet (téves vélekedés tulajdonítása) - mentális reprezentációkat reprezentálunk 
(metareprezentáció). ${ }^{2}$ Frith elképzelése szerint gazdagítja a tünetek magyarázatának lehetőségét, ha a három terület elkülönítésén túl feltételezzük azt is, hogy a metareprezentációk tartalma

- leszakadhat: ha bizonytalanná válik, hogy a reprezentációs tartalom valójában mely ágenshez tartozik. Ez magyarázhatja meg például a 2. személyú hallucinációkat, az idegen kontroll érzését, a gondolatbehelyezést stb. Például I intend to „catch the bus” (el akarom érni a buszt) helyett „catch the bus” (érd el a buszt) (FrITH, 1992, 127).

- sérülhet: ha a reprezentációs tartalom nem fedi a valóságot. Ez magyarázhatja meg például a nagyzásos téveszméket, paranoid gondolatokat stb. Például I must "go to work" (dolgoznom kell) helyett I must become the boss (fönöknek kell lennem) (FRITH, 1992, 127).

- kiüresedhet: ha az egészségeseknél tapasztalható mentalizációs aktivitás csökken. Ez magyarázhatja a katatón állapotot, az akaratszegénységet, a visszahúzódást stb. Például I intend to ,catch the bus” (el akarom érni a buszt) helyett I intend to ”, "(nincs beolvasható szándék) (FRITH, 1992, 127).

Frithnek e szinte mindent felölelő, egységesítő elméletét követően elindultak az empirikus kutatások. A vizsgálatok sokszínűségét bemutatandó foglaljuk össze az eddig megszületett eredményeket.

\section{EGY KOGNITÍV ELMÉLET MEGTERMÉKENYÍTŐ HATÁSA A PSZICHIÁTRIÁBAN}

\section{Az elsö kutatások a Frith elmélet nyomán}

C. Frith, aki az elmélet-vezérelt kutatások elkötelezett híve és munkatársa, Corcoran (CORCORAN, FriTh, 1996; CORCORAN, MERCER, Frith, 1995; CorCORAN, CAHILL, FRITH, 1997; FRITH, CORCORAN, 1996) olyan kísérletsorozatot végeztek el, amelyben Frith elméletére alapozva azt a kérdést igyekeztek első ízben megközelíteni, hogy problémát jelent-e különböző szkizofrén betegek számára más emberek vélekedéseinek, szándékainak a kikövetkeztetése.

A kísérletek során lehetőséget teremtettek a finomabb megközelítésre, érvényesítve azt a fontos szempontot, hogy a szkizofrén betegek tüneteik alapján kisebb alkategóriákba sorolhatók. Ez a csoportosítás nemcsak megkönnyíti a betegek besorolását, de a tünetek és funkciózavarok kapcsolatának tisztázásához, illetve magának az elméletnek a finomításához is vezethet.

1. Negatív viselkedéses jegyek: visszahúzódás, tompa érzelmek, abúlia, szegényes beszéd;

${ }^{2}$ A mentalizáció nem mindig áll meg ezen a szinten: például ha már azt is tudjuk, hogy a főnök tudja, hogy mi tudjuk, hogy ő is tévedhet. A tudatelméleti feladatok nehézségi szintjét befolyásolhatjuk azzal, hogy egyszerủ metareprezentációt igénylő, elsőrendủ vagy magasabb rendủ feladatokat alkalmazunk. 
2. Pozitív viselkedéses jelek (negatív jegyek nélkül): a formális gondolkodás zavara, dezorganizált viselkedés, inkongruens érzelmek;

3. Paranoid téveszme (viselkedéses jegyek nélkül): vonatkoztatási, üldöztetési téveszme, félreértelmezés, gondolatolvasási téveszme, 3. személyủ és üldöztetéses hallási hallucináció;

4. Passzivitási tünetek (viselkedéses tünetek és paranoid téveszme nélkül): befolyásoltatásos és gondolatbehelyezési téveszme, 2. személyű hallási hallucináció;

5. Egyéb tünetek (fentiek közül egyik sem, de más kevésbé tipikus tünetek): zenei hallucináció, szexuális, hipochondriás és nagyzásos téveszmék;

6. Remisszió: legalább két hétig nem jelentkezik a fentiek közül egyik sem (CORCORAN, 2000).

A kutatások egészséges és nem szkizofrén betegeket is alkalmaztak kontrollcsoportként. Négyféle módszerrel próbálták megragadni a tudatelméleti nehézségeket. Először (CORCORAN, MERCER, FRITH, 1995) olyan szituációk megértését vizsgálták, ahol a beszélőnek egy erős célzásban elrejtett szándékát kellett kikövetkeztetnie. Ahogyan a kontrollcsoportoknak sem, a passzív és remissziós csoport számára sem jelentett problémát a feladat. A másik három csoportnak viszont nehezen ment. Egészében nézve a szkizofrén betegcsoportokat, teljesítményük korrelált az IQ-val, ami arra utal, hogy ehhez az egyszerű feladathoz általános kognitív képességeikre támaszkodtak, miközben az egészséges és nem szkizofrén betegcsoport esetében ilyen összefüggés nem volt.

A téves vélekedés és becsapás tesztelésénél (FRITH, CORCORAN, 1996) a negatív viselkedéses jegyeket mutató és a paranoid csoportnál mutatkoztak problémák.

Rajzos viccek megértését tesztelve (CORCORAN, CAHILL, FRITH, 1997) kiderült, hogy a mentális állapot megértését igénylő és nem igénylő tréfák csak a kontrollcsoportok és a remissziós betegek számára voltak egyformán könnyűek. Különösen a negatív viselkedéses jegyeket mutató és a paranoid csoport számára jelentett nehézséget a mentalizálást megkövetelő vicc megértése.

A pozitív és negatív viselkedéses jegyeket mutató csoportnál szélesebb körü szociokognitív nehézségeket találtak. A paranoid csoport esetében csak az udvariassággal kapcsolatban mutattak ki nehézségeket, viszont az előbbieknél a társalgás grice-i maximáinak betartásával is problémák voltak (CORCORAN, FRITH, 1996).

CORCORAN (2000) interpretációja szerint fontos a nyilvánvaló deficit kimutatásán túl, hogy a negatív viselkedéses csoport esetében - akik adott esetben például a feladathoz tartozó kontrollkérdéseket nem tudták megválaszolni - általánosabb kognitív problémáról van szó, amit az egyéb kognitív neuropszichológiai vizsgálatok is alátámasztanak. A paranoid betegek esetében azonban specifikus problémáról lehet szó. A remissziós csoport következetes sikere a feladatokban arra utalhat, hogy állapotszerủ lehet a tudatelméleti deficit. A krónikus, nem remittáló negatív viselkedéses jegyeket mutató betegek esetében ugyanez a deficit így állandósulni látszik.

E nagyszabású, az elméletet első ízben tesztelő vizsgálatsorozat után több kutatás született a témában, amelyek hozzájárulnak az elmélet legalapvetőbb kérdéseinek tisztázásához. Ezeknek legnagyobb részében a független változót a speciális 
célcsoportok alkalmazása jelenti, illetve újabb eszközök segítségével igyekeztek kimutatni ezeknél a csoportoknál a tudatelméleti deficitet.

\section{Tudatelméleti feladatok különböző szkizofrén betegcsoportok esetében}

LANGDON (1997) mentális és különböző nem mentális képek sorrendezéssel, a magyarázatokban alkalmazott mentális nyelv és a saját mentális állapotokra való emlékezés segítségével mutatott ki deficitet szkizofrén betegeknél, különösen a negatív tünetes, autisztikus betegeknél.

A SARFATI $(1997 \mathrm{a}, \mathrm{b})$ által vizsgált szkizofréniás betegek számára nehezebb feladatnak mutatkozott a szándék, mint a hamis vélekedés tulajdonítása. Feltehetően a nagyobb komplexitás nehezíti meg az utóbbi esetben a feladatot. A formális gondolkodás zavarát mutató betegek esetében az előbbi feladat is kissé nehezebbnek bizonyult. Sarfati szerint elképzelhető, hogy nem arról van szó, hogy a betegek egyáltalán nem mentalizálnak, hanem a probléma a következtetési folyamathoz szükséges releváns kontextuális információ emelésével van. Későbbi vizsgálatok kimutatták a szándék- és vágytulajdonítás nehézségét gondolkodás- és beszédzavart mutató szkizofréniás betegeknél (SARFATI, HARDY-BAYLÉ, 1999).

DOODY, GÖTZ, JOHNSTONE, Frith és CUNNINGHAM OWENS (1998) első- és másodrendủ tudatelmélet-feladatokat alkalmazott. A szkizofréniás betegek számára csak az utóbbi jelentett gondot. Ugyanakkor a tanulási nehézséggel is küzdő szkizofrén betegek számára jelentett a feladat a legnagyobb nehézséget, beleértve a kontrollkérdések megválaszolását is.

Mitchley, BARber, GRAY, BROOKS, Livingstone (1998) az irónia megértésén keresztül vizsgált szkizofrén betegeket. Az irónia szó szerint való értelmezése gyakoribb volt a szkizofrén betegcsoportban - különösen a negatív tünetesek esetében -, mint a nem pszichotikus pszichiátriai csoport esetében.

PICKUP (doktori tézis, idézi CORCORAN, 2000) a téves vélekedés feladatok, illetve szerkezetükben ezeknek megfeleltetve nem mentális feladatok segítségével megmutatta, hogy a másodrendủ mentális feladatok esetében van probléma szkizofréniás betegeknél. Pilowsky, YiRIMIYA, ARBELLE, MOZES (2000) a hamis vélekedés és a becsapás megértésén keresztül gyermekkorú szkizofrén betegeknél mutatta ki a tudatelmélet érintettségét.

\section{A tudatelmélet érintettsége egészséges felnőtteknél}

Immár tünetmentes személyekre is kiterjednek a vizsgálatok - demonstrálva a pszichiátriában egyre erősödő kontinuumelképzelést. LANGDON és COLTHEART (1999) szkizotípiás, de egészséges személyeknél mutatott ki képsorrendezés segítségével gyenge mentalizációt. KINDERMAN, DUNBAR, BENTALL (1998) olyan egészséges személyeknél talált problémát a mentalizációban, akiknek az attribúciós stílusára jellemző, hogy általában negatív eseményért más személyt okolnak. 


\section{EL NEM HALLGATHATÓ ELŐZMÉNYEK}

Az eddig megszületett eredmények összefoglalása után térjünk ki arra, amiről eddig hallgattunk. Hiszen amikor C. Frith a tudatelmélet zavarát teszi felelőssé a szkizofrénia tüneteiért, akkor egy olyan mechanizmus sérülését feltételezi, amely az utóbbi 15-20 évben a kognitív pszichológia egyik legtöbbet kutatott területe. Az 1980-as évek elején megjelenő hamis vélekedés tesztek után óriási számban születtek olyan tanulmányok, amelyek a tudatelmélet ontogenetikus fejlődésével foglalkoztak. A különböző életkorok teszteléséről, illetve új meg új eszközök alkalmazásáról adtak hírt a tanulmányok. A szkizofrénia-kutatás mai állása talán a korai tudatelmélet-kutatásoknak ehhez a fázisához hasonlítható. A tudatelmélet kérdése nem csupán a fejlődéspszichológia, hanem az elmefilozófia és az evolúciós megközelítés számára is vetett fel érdekes kérdéseket, ezzel meghonosítva e területen is a kognitív tudományban szokásos interdiszciplináris megközelítést. Jellemző továbbá a fejlődés-pszichopatológiai megközelítés is, amelynek köszönhetően széles körű autizmuskutatások zajlanak. Az autizmus tudatelmélet-hipotézisének alapgondolata - amely teória csak egy a versenyképes autizmuselméletek közül, és amely hét évvel fiatalabb a szkizofrénia tudatelmélet hipotézisénél (BARONCOHEN, Leslie, U. FriTh, 1985) - az, hogy a legföbb tünetek a tudatelmélet problémájával magyarázhatók. Lerövidítve ezt a szintén bonyolult kérdést, a Wing triász-zavar a szociális interakciók területén (autisztikus magány), a kommunikációban, a rugalmas viselkedés szervezésben (például spontán mintha játékban) a mentalizációs képesség hiányával magyarázható. Nem a szkizofrénia tehát az első olyan mentális zavar, amelynek magyarázatára a tudatelmélet sérülését feltételezik. A szkizofrénia negatív tünetei - visszahúzódás, szegényes beszéd, a nyelv pragmatikája érintett, sztereotip viselkedés - nagyon hasonlítanak az autizmus fent említett legfontosabb tüneteihez. Ugyanakkor az elméleteknek számolni kell a két betegség között rejlő különbségekkel is. Az autizmusra korai (fejlődési zavarról van szó), míg a szkizofréniára késôi kezdet jellemző (megszerzett képesség elvesztése), illetve a szkizofrénia pozitív tünetei hiányoznak az autizmus kórképéből.

Az autizmus-kutatásokban lassan véget ért a kísérletet kísérletre halmozó, feltáró, exploráló időszak. Miután kirajzolódtak a kérdéskör főbb vonalai, megjelentek az első kétségek és rájuk válaszképpen az első segédhipotézisek, egyre inkább elméletvezéreltté váltak a kutatások. Az egymással versengő teóriák egyre szofisztikáltabb módszerekre inspirálták a kutatókat.

A tudatelméletkutatás és az autizmus tudatelmélet-hipotézise az elmúlt években számos elméleti és empirikus nehézséggel került szembe. Korántsem mondható, hogy mindegyikkel megküzdött, de a tudományos elméletek szokásos fejlődési folyamatában meglehetősen nagy utat tett már meg.

Ennek fényében vessünk még egy pillantást újra a szkizofréniakutatásra, amely önmagában tekintve még a fejlődés korai stádiumában van. De beleillesztve a tudatelmélet-kutatás történetébe, talán nem reagálunk türelmetlenül, ha most kicsit kritikusabban közelítünk az eddigi vizsgálatokhoz. 


\section{A SZKIZOFRÉNIA TUDATELMÉLET-KUTATÁSÁNAK KRITIKÁJA}

Igazodva a szkizofrénia tünettanának szelleméhez, a kutatásokkal kapcsolatos felmerülő módszertani problémákat, kérdéseket ezek „pozitív és negatív tüneteiként" mutatjuk be.

\section{„Negatív tünetek”}

A kutatások negatív tüneteinek tekinthetjük azt, ami hiányzik a kutatásokból ahhoz, hogy érvényes és megbízható, illetve a kognitív pszichológia számára is hasznos eredmények szülessenek.

\section{Kritika az elmélettel kapcsolatban}

C. Frith a kognitív neuropszichológiai megközelítést alkalmazza a szkizofréniával kapcsolatban. Fontosnak tartja, hogy a pszichózisok tudományos vizsgálata elméletvezérelt legyen (a klinikai pszichiátria felől megfogalmazott ugyanilyen igényt lásd ANDREASEN [1997a]) a vizsgálatok indukálása és az eredmények többféle interpretációja érdekében.

Tehát valamilyen koherens tudás kell, hogy irányítsa és interpretálja a megfigyeléseket. A neuropszichológia számára ilyen kézenfekvő elméletekkel szolgál a kognitív pszichológia, amely a normál kognitív müködések tudományos magyarázatára törekszik.

Minden bizonnyal korai lenne elvárni az első eredmények alapján olyan visszacsatolásokat, amelyek számottevően módosítanának az eredeti elméleten. Egyelőre zömmel olyan kutatások születtek, amelyek azon fáradoznak, hogy kimutassák a tudatelméleti deficitet szkizofréniában. Született már olyan kutatás is, amely pusztán leíró jellegű, meg sem közelíti a Frith által elvárt elméletvezérelt vizsgálódást (Pillowsky, Yirimiya, ARbelle, Mozes, 2000).

Mostanáig kevés az olyan vizsgálat, ahol a tudatelmélet és végrehajtó funkciók vitáit (például Russell, 1997; HARRIS, 1993; CURRIE, 1993), illetve a tudatelméleti feladatok olyan analízisét figyelembe vették volna, amelyek megkísérlik szétválasztani a tudatelmélet modul és egyéb faktorok szerepét a téves vélekedés feladatokban (ROTH, LESLIE, 1998).

Próbálkozás történt erre vonatkozóan Pickup (doktori tézis, idézi CORCORAN, 2000), illetve LANGDON és COLTHEART (1999) vizsgálataiban, amelyekben a végrehajtó működést és a tudatelméleti képességet is mérték. De ezekre a „pozitív tünetek" között térünk vissza, mivel megpróbálkoztak a szélesebb elméleti megalapozással, de nem biztos, hogy mindig elég körültekintően.

A fejlődéslélektani kutatások ki- és felhasználása feltehetően a továbbiakban is sokat lendíthet a kutatásokon, hiszen az áttekintésben előkerült tudatelméleti feladatok, módszerek mindegyike a fejlődéslélektani kutatásokban gyökerezik. 
Kritika a módszerrel kapcsolatban

Gyakori hiányossága a korai kísérleteknek, hogy egyáltalán nem alkalmaznak a mentális feladatok mellett nem mentális feladatokat. Ha mégis, nem tesznek kísérletet arra, hogy ezeket szerkezetükben illesszék a mentális feladatokhoz és nehézségi fokban is kontrollálják őket (DOODY, GÖTZ, JOHNSTONE, FRITH, Cunningham OWens, 1998; Frith, Corcoran, 1996; PIllowsky, YirimiYa, ARbelle, MOZES, 2000; SARFATI, HARDY-BAYLÉ, 1999). Így nem zárható ki annak a lehetősége, hogy a teljesítményt a mentalizáláson túl más is befolyásolhatja.

Gyakran előfordul az is, hogy a kontrollkérdések okozta k. sz. veszteség után fel sem merül a feladat újragondolása (DOODY, GÖTZ, JOHNSTONE, FriTH, Cunningham Owens, 1998; Frith, CorCORAn, 1996), mivel elfogadott, hogy bizonyos betegcsoportoknál általánosabb kognitív zavar áll fenn. Ez esetben viszont elvész a minták jelentős része, hiszen a meglévő feladattal mérhetetlenné válik az eredetileg megcélzott képesség.

\section{„Pozitív tünetek”}

A kutatások pozitív tüneteinek nevezhetjük az olyan hibákat, problémákat, amelyek bizonytalanná teszik az eredmények érvényességét és megbízhatóságát, illetve azt, hogy a kognitív pszichológia számára is hasznos eredmények szülessenek.

Kritika az elmélettel és a módszerrel kapcsolatban

Langdon, Coltheart (1999) és Pickup (doktori tézis, idézi CORCORAN, 2000) elméleti megfontolásból alkalmaznak végrehajtó működést mérő tesztet: az előbbiek csak a több faktort is tartalmazó Hanoi tornyot, az utóbbi pedig téri diszkriminációs feladatot. Esetükben nem lehetünk biztosak abban, hogy ezek olyan nem mentális feladatok, amelyek a végrehajtó működés szempontjából megegyeznek az adott tudatelmélet-feladattal.

A korábbi kutatásokat felhasználva előfordul többféle feladattípus alkalmazása. Ám kiválasztásuk nem mindig elméletfüggő. Általában nem ellenőrzik, hogy a feladatok ugyanazt mérik-e, mégsem kezelik óket független változóként (PILlOwSKY, YIRIMIYA, ARBELLE, MOZES, 2000; FRITH, CORCORAN, 1996).

Kinderman, Dunbar, BENTALl (1998) egymástól függetlennek szánt mérést végez a tudatelmélet és az attribúciós stílus meghatározására, majd összefüggésbe hozza az előbbi teszten mért gyengébb teljesítményt paranoid tendenciákkal. A feladatokat ellenőrizve azonban felfedezhetjük, hogy a tudatelméleti feladat bizonyos téves megoldásai valójában paranoid válasznak is tekinthetők. Tehát nem azt mérte, amit valójában megcélzott. Úgy is mondhatjuk, hogy az eredmény előre bele volt kódolva az alkalmazott tesztbe.

Hasonló probléma fedezhető fel SARFATI és HARDY-BAYLÉ (1999) feladatai között, amikor feltételezik, hogy a szkizofrén betegek egy képsorozat befejezéseképpen a helyes szándék tulajdonítása helyett a hétköznapokban leggyakrabban tapasztalható befejezést választják. Az egyik (a két ismertetett közül) példájukban azonban a gyakorinak tekintett befejezés lehetséges és értelmes szándék tulajdonításaként is felfogható. 


\section{Kritika a kisérleti személyekkel kapcsolatban}

Láthattuk az összefoglalóból, hogy sokféle betegcsoportot vizsgáltak már. Fontos szem előtt tartani, hogy nem kis feladat sem egy homogénnek tekinthető betegcsoport kialakítása, sem a betegségen kívüli egyéb különbségek kontrollja. Ezért is fontos a megfelelő mintanagyság a kísérletek során.

A kontrollkérdések alkalmazása miatt gyakran radikálisan csökken a résztvevők száma, tehát ez szintén veszélyezteti a minta reprezentativitását és nagyságát (Frith, CORCORAn, 1996; DoOdy, GÖTZ, JOHnStone, Frith, Cunningham OWENS, 1998).

Mindezeket az észrevételeinket annak reményében fogalmaztuk meg, hogy a szkizofrénia tudatelmélet-kutatása az eddigi tudatelmélet-kutatások szerves részeként fejlődik tovább, s így megfelelő körültekintéssel nem születik túl sok olyan kutatás, amely csak a divatnak hódolva gyártja az olyan eredményeket, amelyek nem képesek a kognitív pszichológia elméleti kérdéseivel kapcsolatba kerülni, azokból meríteni és számukra inspiráló visszacsatolásokkal szolgálni.

\section{IRODALOM}

ANDREASEN (1997) Linking mind and brain in the study of mental illnesses: A project for a scientific Psychopathology. Science, Vol 275, 14 March, 1586-1593.

Andreasen, N. C. (1982) Negative symptoms in schizophrenia: Definition and reability. Archives of General Psychiatry, 39, 784-788.

Baron-Cohen, S., Leslie, A., Frith, U. (1985) Does the autistic child have a „theory of mind"? Cognition, 21, 37-46.

BITTER I., FÜREDI J. (szerk.) (2000) Szkizofrénia. Medicina Könyvkiadó, Budapest

CorCoran, R. (2000) Theory of mind in other clinical conditions: is a selective "theory of mind" deficit exclusive to autism? In Baron-Cohen, S., Tager-Flusberg, H., Cohen, D. J. (eds) Understanding Other Minds. 391-421. Oxford University Press, Oxford

Corcoran, R., Cahill, C., Frith, C. D. (1997) The appreciation of visual jokes in people with schizophrenia: a study of 'mentalizing' ability. Schizophrenia Research, 24, 319-327.

Corcoran, R., Frith, C. D. (1996) Conversational conduct and the symptoms of schizophrenia. Cognitive Neuropsychiatry, 1, 305-318.

Corcoran, R., Mercer, G., Frith, C. D. (1995) Schizophrenia symptomatology and social inference; investigating theory of mind in people with schizophrenia. Schizophrenia Research, 17, 5-13.

CROw (1980) Molecular pathology of schizophrenia: more than one disease process? BMJ, $280,1-9$

CURrie, G. (1993) Simulation-theory, theory-theory and the evidence from autism. In Baron-Cohen, S., Tager-Flusberg, H., Cohen, D. J. (eds) Understanding Other Minds. 242-256. Oxford University Press, Oxford

Dennett, D. (1996) Micsoda elmék. A tudatosság megértése felé. Kulturtrade Kiadó, Budapest

Doody, G. A., Götz, M., Johnstone, E. C., Frith, C. D., Cunningham Owens, D. G. (1998) Theory of mind and psychoses. Psychological Medicine, 28, 397-405.

FriTh, C. D. (1992) The Cognitive Neuropsychology of Schizophrenia. Laurence Erlbaum Assiciates, Hove, Taylor \& Francis 
FrITH, C. D. (1994) Theory of Mind in Schizophrenia. In David, A. S., Cutting, J. C. (eds) The Neuropsychology of Schizophrenia. 147-161. Psychology Press, Hove

Frith, C. D., CorCorAn, R. (1996) Exploring „theory of mind” in people with schizophrenia. Psychological Medicine, 26, 521-530.

Green, F. G. (1998) Schizophrenia from a Neurocognitive Perspective. Allyn and Bacon, Boston

HARris, P. (1993) Pretending and planning. In Baron-Cohen, S., Tager-Flusberg, H., Cohen, D. J. (eds) Understanding Other Minds. 228-245. Oxford University Press, Oxford

Kinderman, P., Dunbar, R., Bentall, R. P. (1998) Theory-of-mind deficits and causal attributions. British Journal of Psychology, 89, 191-204.

LAngdon, R., Coltheart (1999) Mentalizing, schizotypya and schizophrenia. Cognition, $71,43-71$.

Langdon, R., Michie, P. T., Ward, P. B., McConaghy, N., Catts, S. V., Coltheart, M. (1997) Defective self and/or other mentalizing in schizophrenia: a cognitive neuropsychological approach. Cognitive Neuropsychiatry, 2, 167-193.

Mitchley, N. J., Barber, J., Gray, J. M., Brooks, D. N., Livingstone, M. G. (1998) Comprehension of irony in schizophrenia. Cognitive Neuropsychiatry, 3, 127-138.

Pilowsky, T., Yirimiya, N., Arbelle, S., Mozes, T. (2000) Theory of mind abilities of children with schizophrenia, children with autism, and normal developing children. Schizophrenia Research, 42, 145-155.

Roth, D., LeSLIE, A. M. (1998) Solving belief problems: toward a task analysis. Cognition, $66,1-31$.

Russel, J. (1997) How executive disorders can bring about an inadequate "theory of mind". In Autism as an Executive Disorder. 256-304. Oxford University Press, Oxford

SARfati, Y., Hardy-Baylé, M. C. (1999) How do people with schizophrenia explain the behaviour of others? A study of theory of mind and its relationship to thought and speech disorganizations in schizophrenia. Psychological Medicine, 29, 613-620.

Sarfati, Y., Hardy-Baylé, M. C., Besche, C., Widlocher, D. (1997a) Attribution of intentions to others in people with schizophrenia: a non-verbal exploration with comic strips. Schizophrenia Research, 25, 199-209.

Sarfati, Y., Hardy-Baylé, M. C., Nadel, J., Chevalier, J-F., Widlocher, D. (1997b) Attribution of mental states to others by schizophrenic patients. Cognitive Neuropsychiatry, 2, 1-17.

\title{
SCHIZOPHRENIA AND THEORY OF MIND RESEARCH
}

\author{
EGYED, KATALIN-JUHÁSZ, LEVENTE ZSOLT
}

This article introduces a caracteristic model of neurocognitive theories of schizophrenia: the hypothesis of the theory of mind deficit. According to C. FRITH (1992) most of the signs and symptoms of schizophrenia are consequences of the impairment of a unique cognitive function, the impairment of mentalizing ability. In our paper we outline a critical review of current empirical findings of this filed on the basis of cognitive developmental research on the theory of mind involving investigations related to autism.

Key words: $\quad$ schizophrenia, theory of mind, executive functions, autism 